\title{
Committees of the American Political Science Association
}

\section{Constitutional Committees}

\section{Administrative Committee}

The Administrative Committee consists of the president, president-elect, treasurer, and four other Council members whose main duties include preparing agendas for Council meetings and annual business meetings, making recommendations to the Council, reviewing the budget and acting on behalf of the Council to dispose of policy issues deemed of insufficient weight to require decisions by the Council.

Robert O. Keohane, Duke University Robert Jervis, Columbia University James A. Stimson, University of North Carolina

William A. Galston, University of Maryland, College Park

Cynthia McClintock, George Washington University

Christine M. Sierra, University of New Mexico

Virginia Sapiro, University of Wisconsin, Madison

\section{Nominating Committee}

The Nominating Committee selects one nominee for each elective office to be filled and submits the slate of candidates for the next annual business meeting, with a report to the president no later than April 15.

Terms expiring December 31, 2000:

Ruth Berins Collier, University of California, Berkeley

Mary Fainsod Katzenstein, Cornell University

Dianne Pinderhughes, University of Illinois, Urbana-Champaign

Terms expiring December 31, 2001:

Robert Axelrod, University of Michigan Elinor Ostrom, Indiana University

David Rohde, Michigan State University, chair

\section{Committee on the Annual Meeting}

Terms 1998-2000:

Ian Lustick, University of Pennsylvania Alan Abramowitz, Emory University
Terms 1999-2001:

Kristi Andersen, Syracuse University Peter Lange, Duke University, chair

Terms 2000-2002:

Janet Box-Steffensmeier, Ohio State University

Virginia Sapiro, University of Wisconsin, Madison

\section{Ex Officio:}

Ira Katznelson, Columbia University

Helen Milner, Columbia University

Robert J-P. Hauck, APSA

Jennifer Richards, APSA

\section{Program Committee}

Program Committee members are approved by the Council at its spring meeting after it receives the selections of the Program Chair-Designate(s). Members organize all panels, plenary sessions, and other aspects of the official program for the annual meeting. Special instructions have been sent to the Program ChairDesignate(s).

Helen Milner, Columbia University, cochair

Ira Katznelson, Columbia University, co-chair

Bernard Yack, University of Wisconsin, Madison

Joan C. Tronto, Hunter College, CUNY

Nancy J. Hirschmann, Cornell University

David P. Baron, Stanford University

Laura Stoker, University of California, Berkeley

John Duggan, University of Rochester

Daniel P. Carpenter, University of Michigan

Gerald Gamm, University of Rochester

John Williams, Indiana University

Mark P. Petracca, University of California, Irvine

Pernilla M. Neal, Dickinson College

Melanie Manion, University of Rochester

Susan Stokes, University of Chicago

Stephen E. Hanson, University of Washington

Geoffrey Garrett, Yale University

Jytte Klausen, Brandeis University

Jeffry Frieden, Harvard University

Joanne Gowa, Princeton University

Peter Feaver, Duke University

Pia Christina Wood, Wake Forest University

Stephen M. Saideman, Texas Tech University
James D. Morrow, Stanford University

Patricia Freeland, University of Tennessee

Bruce Miroff, University at Albany, SUNY

Gregory B. Lewis, Georgia State University

Gary Mucciaroni, Temple University

Paul J. Quirk, University of Illinois, Urbana-Champaign

Roy B. Flemming, Texas A\&M University

Gerald N. Rosenberg, University of Chicago

John Kincaid, Lafayette College

Kim Quaile Hill, Texas A\&M University

J. Phillip Thompson, Columbia University

Barbara Ferman, Temple University

Gwendolyn Mink, University of California, Santa Cruz

Cathy Cohen, Yale University

Mitchell F. Rice, Texas A\&M University

James L. Guth, Furman University

Burt L. Monroe, Indiana University

Paul Allen Beck, Ohio State University

Katherine Tate, University of California, Irvine

Jon Hurwitz, University of Pittsburgh

Darrell M. West, Brown University

David Guston, Rutgers University

Michael C. Gizzi, Mesa State College

Joseph M. Knippenberg, Oglethorpe University

R. Claire Snyder, Illinois State University

Stephen Woolpert, Saint Mary's College of California

Jack S. Levy, Rutgers University

\section{Trust and Development Board of Trustees}

The Trust and Development Board of Trustees consists of the treasurer of the Association, who serves ex officio as chair, and six other trustees who direct the investment of resources.

Terms expiring December 31, 2000:

John Kingdon, George Washington University

Susan Pharr, Harvard University

Terms expiring December 31, 2001:

Penny Miller, University of Kentucky Eddie Williams, Joint Center for Politi$\mathrm{cal}$ and Economic Studies 
Terms expiring December 2002:

Benjamin Cohen, University of California, Santa Barbara

Timothy Cook, Williams College

\section{Council Committees}

\section{Elections Committee}

Three members are appointed after the election from among newly elected and continuing Council members. The committee supervises the conduct of Association elections.

Randall Calvert, Washington University

Nancy E. McGlen, Niagara University, chair

David Rayside, University of Toronto

\section{Rules Committee}

Three members are appointed after the election from among newly elected and continuing Council members. The committee reviews the Association's By-Laws and Rules of Procedure for governing the conduct of the annual business meeting and proposes revisions as they are deemed necessary.

Edmond J. Keller, University of California, Los Angeles

George Marcus, Williams College

Eileen L. McDonagh, Northeastern University, chair

\section{Council Authorized Committees and Special Purpose Committees}

\section{Rowman \& Littlefield Award Committee}

This award is given annually to recognize political scientists who have developed effective new approaches to teaching in the discipline.

L. Sandy Maisel, Colby College, chair $(2000-01)$

Ole R. Holsti, Duke University (2000)

Kristen R. Monroe, University of California, Irvine (2000-2001)

Bernard J. O'Connor, Eastern Michigan University $(2000)$

Sheilah Mann, APSA, ex officio

\section{Strategic Planning Committee}

John H. Aldrich, Duke University

Paul Allen Beck, Ohio State University, chair

Luis Fraga, Stanford University

Nancy E. McGlen, Niagara University

Marion Orr, Brown University

Ronald Rogowski, University of California, Los Angeles

Kay Lehman Schlozman, Boston College
Beth Simmons, University of California, Berkeley

Sven Steinmo, University of Colorado, Boulder

Joan Tronto, Hunter College, CUNY

\section{Congressional Fellowship Program Advisory Committee}

The Congressional Fellowship Program Advisory Committee provides overall

policy guidance for the program and has its own selection procedures.

Michael Barone, U.S. News \& World Report

Walter D. Broadnax, American University

Creed C. Black, John S. and James L. Knight Foundation

David Broder, The Washington Post

Sam Brownback, U.S. Senate

Richard E. Cohen, National Journal

Tom Daschle, U.S. Senate

Robert Dole, U.S. Senate (Ret.)

Jerelyn Eddings, U.S. News \& World Report

Eugene Eidenberg, The Carlyle Group

Thomas S. Foley, American Embassy, Tokyo

David R. Gergen, U.S. News \& World Report

Stephen Horn, U.S. House of Representatives

Albert R. Hunt, Wall Street Journal

Gerald Kovach, MCI WorldCom

Richard Lugar, U.S. Senate

Robert W. Merry, Congressional Quarterly, Inc.

Leonard Parkinson, Atlantic Research Corporation

David Price, U.S. House of Representatives

Cokie Roberts, ABC News

Josette Shiner, Empower America

Barbara Sinclair, University of California, Los Angeles

Janet D. Steiger, Federal Trade Commission

Charls E. Walker, Walker and Walker, LLC

Vin Weber, Empower America

\section{Committee on Departmental Services}

The Committee on Departmental Services advises on publications and other services for members of the Association's Departmental Services Program.

Terms expiring December 31, 2000:

Ronald Peters Jr., University of Oklahoma, chair

Kathleen Jones, San Diego State University
Terms expiring December 31, 2001:

Sheila Ards, Benedict College

Harold Stanley, University of Rochester

Terms expiring December 31, 2002

Marion Just, Wellesley College

James Sheffield, Wichita State University

\section{Editorial Board, PS}

The PS Editorial Board consists of fifteen members who advise the editor on the content of each issue.

Terms expiring December 31, 2000:

Mark Petracca, University of California, Irvine

William Jacoby, University of South Carolina

Robert W. Bailey, Rutgers University, Camden

Karen Beckwith, College of Wooster

Leonie Huddy, SUNY, Stony Brook

Terms expiring December 31, 2001:

Christine Marie Sierra, University of New Mexico

John Rouse, Ball State University

Marian Lief Palley, University of Delaware

Charlotte Ku, American Society of International Law

Jeffrey Legro, University of Virginia, chair

Terms expiring December 31, 2002:

John Freeman, University of Minnesota Bert Buzan, California State University, Fullerton

John Mollenkoff, City University of New York

Barbara Connolly, Tufts University

Christine Di Stefano, University of Washington

Robert Goodin, Australian National University

\section{Committee on Publications}

The Committee on Publications has six members, in addition to ex officio members. The Committee oversees and coordinates existing APSA publications, explores possible relationships with political science journals not sponsored by the Association, and develops proposals for new publications when appropriate.

Terms expiring December 31, 2000:

Jack Citrin, University of California, Berkeley

Richard Herrera, Arizona State University 
Terms expiring December 31, 2001:

Jon Bond, Texas A\&M University

Bert Rockman, University of Pittsburgh, chair

Terms expiring December 31, 2002:

Nathaniel Beck, University of California, San Diego

Susan Welch, Pennsylvania State University

Ex officio:

Jeffrey Legro, University of Virginia, $(P S)$

Ada W. Finifter, Michigan State University $(A P S R)$

\section{Committee on Education and Professional Development}

The Committee on Education and Professional Development consists of seven members who develop, coordinate, and review educational programs and activities following guidelines outlined by the Council.

Terms expiring December 31, 2000:

Charles Johnson, Texas A\&M University, chair

Judith Torney-Purta, University of Maryland, College Park

Kent Brudney, Cuesta Community College (CA)

Terms expiring December 31, 2001

Steven Schier, Carleton College

Michael Ward, University of Washington

Terms ending December 31, 2002:

Anne Costain, University of Colorado, Boulder

\section{Committee on International Programs}

This committee was created by the Council to develop relationships between American political science and political science in other nations. It oversees bilateral exchanges, Senior Scholar and Foreign Student Travel Grants to APSA's Annual Meeting, the selection of travel fellows of the American Council of Learned Societies, the APSA's relationship with the International Political Science Association and other non-U.S. national and international associations.

Terms expiring December 31, 2000:

James Gibson, Washington University, chair

Jean Oi, Stanford University
Terms expiring December 31, 2001:

K.C. Morrison, University of Missouri, Columbia

Nicole de Montricher, Paris, France

Terms expiring December 31, 2002:

Germaine A. Hoston, University of California, San Diego

Fritz Scharpf, Max Planck Institute, Koln, Germany

Committee on Professional Ethics, Rights and Freedoms

The Committee on Professional Ethics, Rights and Freedoms' responsibility is to protect the rights of political scientists and ensure that the ethical policies of the Association are followed.

Terms expiring December 31, 2000:

Matthew Moen, University of Maine, chair

Wendy Brown, University of California, Santa Cruz

Terms expiring December 31, 2001:

Mamie Locke, Hampton University Stanley Kelly, Princeton University

Terms expiring December 31, 2002:

Elizabeth Kiss, Duke University

Catherine Zuckert, Notre Dame University

\section{Research Support Advisory Board}

The Research Support Committee oversees activities regarding public and private research support for political scientists.

Terms expiring December 31, 2000:

W. Russell Neuman, University of Pennsylvania, chair

Dorothy Solinger, University of California, Irvine

Terms expiring December 31, 2001:

Nolan Jones, National Governors' Association

James Alt, Harvard University

Terms expiring December 31, 2002:

Carol Nackenoff, Swarthmore College

Michael Alvarez, California Institute of Technology

Committee on the Status of Blacks in the Profession

The Committee on the Status of Blacks in the Profession develops and promotes activities concerning the professional development of blacks within the discipline.

Terms expiring December 31, 2000:

Ron Brown, Wayne State University Cheryl Miller, University of Maryland, Baltimore, chair

Terms expiring December 31, 2001:

Victor James, Laney College

Desiree Pedescleaux, Spelman College

Terms expiring December 31, 2002:

Franklin Gilliam, University of California, Los Angeles

Edward Thompson III, California State University, San Marcos

Committee on the Status of Latinos in the Profession

The Committee on the Status of Latinos in the Profession develops and promotes activities concerning the professional development of Latinos within the discipline.

Terms expiring December 31, 2000:

Manuel Avalos, Arizona State University West

Linda Lopez, Chapman University

Terms expiring December 31, 2001:

Gary Segura, Claremont Graduate University

Carol Hardy-Fanta, University of Massachusetts, Amherst

Terms expiring December 31, 2002:

Ron Schmidt Sr., California State University, Long Beach

Valerie Martinez-Ebers, Texas Christian University, chair

Committee on the Status of Women in the Profession

The Committee on the Status of Women in the Profession develops and promotes activities concerning the professional development of women within the discipline.

Terms expiring December 31, 2000:

Janet Flammang, Santa Clara University Susan Moller Okin, Stanford University

Terms expiring December 31, 2001:

Eloise Buker, Denison University, chair Constance Cook, University of Michigan

Terms expiring December 31, 2002:

Susan Burgess, University of Wisconsin, Milwaukee

Shirley Geiger, Savannah State College 


\section{Committee on Endowments}

This committee was authorized by the Council in 1988 to propose development goals and policies to the Council and oversee their eventual implementation.

Terms expiring December 31, 2000:

Samuel Barnes, Georgetown University

Daniel Mulhollan, Congressional Research Service

Terms expiring December 31, 2001:

Michael Preston, University of Southern California

John Mark Hansen, University of Chicago, chair

Terms expiring December 31, 2002:

Martha Joynt Kumar, Towson State University

Ronald Rapoport, William \& Mary College

Committee on the Status of Lesbians and Gays in the Profession

This committee assesses the status of gay and lesbian scholars in the profession, advances the research on gay and lesbian issues, develops curriculum materials, and works to ensure tolerance toward gay and lesbian political scientists.

Terms expiring December 31, 2000:

Jodi Dean, Hobart and William Smith Colleges

Ann-Marie Smith, Cornell University

Terms expiring December 31, 2001:

Michele Berger, University of Nevada, Las Vegas

Shane Phelan, University of New Mexico, chair

Terms expiring December 31, 2002:

Steven Haeberle, University of Alabama, Birmingham

Ken Yeager, San Jose State University

\section{Committee on Organized Sections}

The role of the committee is to help Organized Sections carry out their work and to oversee the balance between Sections and APSA as a whole.

Terms expiring December 31, 2000:

Karen Orren, University of California, Los Angeles

Kenneth C. Williams, Michigan State University
Terms expiring December 31, 2001:

Shirley Ann Warshaw, Gettysberg College

James McCormick, Iowa State University, chair

Terms expiring December 31, 2002:

Randall Calvert, Washington University Jane Fountain, Harvard University

\section{Award Committees}

\section{Gabriel A. Almond Award}

This award is given each year for the best doctoral dissertation completed and accepted that year or the previous one in the field of comparative politics.

Karen Alter, Smith College Joel Krieger, Wellesley College, chair Yasheng Huang, Harvard University

\section{William Anderson Award}

This award is given each year to honor the best dissertation completed and accepted during the previous year in the general field of federalism or intergovernmental relations, state and local politics.

Clarence Stone, University of Maryland, College Park, chair

David Walker, University of Connecticut Ann Bowman, University of South Carolina

\section{Edward S. Corwin Award}

This award is for the best doctoral dissertation completed and accepted during that year or the previous year in the field of public law.

Peter Fish, Duke University, chair Murray Dry, Middlebury College Lettie McSpadden, Northern Illinois University

\section{Harold D. Lasswell Award}

This award is for the best doctoral dissertation completed and accepted during that year or the previous year in the field of policy studies and is supported by the Policy Studies Organization.

Vicki Golich, California State University, San Marcos, chair

David Vogel, University of California, Berkeley

Christopher Bailey, University of Keele

\section{Helen Dwight Reid Award}

This award is for the best doctoral dissertation completed and accepted during that year or the previous year in the field of international relations, law and politics and is supported by the Helen Dwight Reid Foundation.

Robert Paarlberg, Wellesley College Debora Spar, Harvard Business School, chair

Etel Solingen, University of California, Irvine

\section{E.E. Schattschneider Award}

This award is for the best doctoral dissertation completed and accepted during that year or the previous year in the field of American government.

Luis Fraga, Stanford University, chair Karen O'Connor, American University Howard Rosenthal, Princeton University

\section{Leo Strauss Award}

This award is for the best doctoral dissertation completed and accepted during that year or the previous year in the field of political philosophy.

Mark Lilla, New York University Susan Shell, Boston College, chair Melissa Williams, University of Toronto

\section{Leonard D. White Award}

This award is for the best doctoral dissertation completed in that year or the previous year in the general field of public administration, including broadly related problems of policy formation and administrative theory.

Joel D. Aberbach, University of California, Los Angeles, chair

Kathy Ferguson, University of Hawaii Cornelius Kerwin, American University

\section{Franklin L. Burdette Pi Sigma Alpha Award}

This award is for the best paper presented at the previous Annual Meeting and is supported by Pi Sigma Alpha.

Evelyn Huber, University of North Carolina, Chapel Hill

Gary King, Harvard University, chair Beth Simmons, University of California, Berkeley

\section{Heinz Eulau Award}

This award is for the best article published in the American Political Science Review in the previous year.

Nancy Bermeo, Princeton University Bryan Jones, University of Washington Lisa Martin, Harvard University, chair

\section{Ralph J. Bunche Award}

This award is for the best scholarly work in political science published in the pre- 
vious year exploring the phenomenon of ethnic and cultural pluralism.

Henry Flores, St. Mary's University (TX)

Marc Howard Ross, Bryn Mawr College, chair

Claire Kim, University of California, Irvine

\section{Gladys M. Kammerer Award}

This award is for the best political science publication in the previous year in the field of U.S. national policy.

Lee Epstein, Washington University

Deborah Stone

Katherine Tate, University of California, Irvine, chair

\section{Victoria Schuck Award}

This award is for the best book on women and politics published in the previous year.

Jane Jaquette, Occidental College

Janet Martin, Bowdoin College

Shannon Stimson, University of California, Berkeley, chair

\section{Woodrow Wilson Foundation Award}

This award is for the best book published in the U.S. in the previous year on government, politics or international affairs and is supported by the Woodrow Wilson Foundation.

John Aldrich, Duke University, chair Raymond Hopkins, Swarthmore College Nancy Rosenblum, Brown University

\section{Carey McWilliams Award}

This award is given to recognize a journalist who has made a substantial contribution to our understanding of politics.

Christopher H. Foreman Jr., The Brookings Institution, chair

Susan Howell, University of New Orleans
Craig Rimmerman, Hobart and William Smith Colleges

\section{Hubert H. Humphrey Award}

This award is given in recognition of notable public service by a political scientist.

Robert Gallucci, Georgetown University Matthew Holden Jr., University of Virginia, chair

Kathryn Sikkink, University of Minnesota

\section{John Gaus Lecture}

This award is to honor the recipient's lifetime of exemplary scholarship in the joint tradition of political science and public administration and, more generally, to recognize achievement and encourage scholarship in public administration.

Jonathan Bendor, Stanford University Camilla Stivers, Cleveland State University

James Q. Wilson, University of California, Los Angeles, chair

\section{APSA Representatives to Affiliated Organizations}

American Association for the Advancement of Science (AAAS)-Section K

Term Expiring February, 2001:

Gary King, Harvard University

American Association for the Advancement of Slavic Studies (AAASS)

Term Expiring December, 2001:

Carol Nechemias, Pennsylvania State University, Harrisburg
American Council of

Learned Societies

Term Expiring December, 2002:

Ronald Kahn, Oberlin College

Consortium of Social

Science Associations

Term Expiring December, 2000:

Clyde Wilcox, Georgetown University

Catherine E. Rudder, American Political Science Association

International Political

Science Association

Term Expiring August, 2000:

Theodore J. Lowi, Cornell University

Paula D. McClain, University of Virginia

Catherine E. Rudder, American Political Science Association

\section{Social Science Research Council}

Term Expiring June, 2001:

Sidney Verba, Harvard University

National Archives and Records Administration Representative

Term Expiring August, 2000:

Martha Joynt Kumar, Towson State University

Representative to the National Coordinating Committee for the Promotion of History

Term Expiring December, 2000:

Martha Joynt Kumar, Towson State University

Representative to U.S. Department of State Advisory Committee on Historical Diplomatic

Documentation

Term expiring September, 2000:

Vincent Davis, University of Kentucky 


\section{PS Index of Authored Articles \\ Volume XXXII, No. 1 (March) through No. 4 (December), 1999}

Abramowitz, Alan I. Explaining Success and Failure in the 1998 Midterm Elections: Comparing the Influence of Swing Voters and Core Party Supporters. March, p. 60.

Ackerman, Bruce. From the Halls of Congress: Political Scientists Testify during Impeachment Hearing. March, p. 24.

Almond, Gabriel, with Wolfgang Krauss. The Size and Composition of the Anti-Nazi Opposition in Germany. September, p. 563.

Andersen, Kristi. The Gender Gap and Experiences with the Welfare State. March, p. 17.

Andres, Gary. Observations on a PostGingrich House. September, p. 571.

Anonymous and Anonymous. Tenure in a Chilly Climate. March, p. 91.

Beer, Samuel H. From the Halls of Congress: Political Scientists Testify during Impeachment Hearing. March, p. 25.

Bennett, Stephen Earl. The Past Need Not Be Prologue: Why Pessimism About Civic Education Is Premature. December, p. 755.

Bennett, Stephen Earl. Rebuttal to Response by Stephen Leonard. December, p. 760.

Bowman, Darcia. The APSA Congressional Fellowship Program: A Job With Options. September, p. 647.

Brock, Kathy L., and Beverly J. Cameron. Enlivening Political Science Courses with Kolb's Learning Preference Model. June, p. 251.

Carroll, Susan J. The Disempowerment of the Gender Gap: Soccer Moms and the 1996 Elections. March, p. 7.

Cook, Timothy E. Treasurer's Report. December, p. 812.

Dulio, David A., Donald L. Goff, and James A. Thurber. Untangled Web: Internet Use during the 1998 Election. March, p. 53.

Durfee, Mary. The Small, Remote, or Odd College: Making the Most Out of Your New Teaching Position. March, p. 109.

Edwards, George C. III. Henry Jones Ford and the American Presidency. June, p. 229.

Ehrlich, Thomas. Civic Education: Lessons Learned. June, p. 245.

Elazar, Daniel J. Tocqueville and the Cultural Basis of American Democracy. June, p. 207.

Finifter, Ada W. APSR Editor's Report. December, p. 803.

Fisher, Louis. Starr's Record as Independent Counsel. September, p. 546.
Frankovic, Kathleen A. Why the Gender Gap Became News in 1996. March, p. 20.

Frantzich, Stephen. Teaching through Tocqueville. June, p. 203.

Frederickson, H. George. The Repositioning of American Public Administration. December, p. 701.

Garand, James C., and Kristy Graddy. Ranking Political Science Departments: Do Publications Matter? March, p. 113.

Goodson, Larry P., Bradford Dillman, and Anil Hira. Ranking the Presses: Political Scientists' Evaluations of Publisher Quality. June, p. 257.

Gourevitch, Peter. Robert O. Keohane: A Biography. September, p. 623.

Hallerberg, Mark, and Bettina Cothran. German Politics auf Deutsch: Teaching Comparative Politics in a Language Across the Curriculum Format. December, p. 739.

Hargrove, Erwin C. Political Science Then and Now: Thoughts on Henry Jones Ford. June, p. 231.

Holden Jr., Matthew. From the Halls of Congress: Political Scientists Testify during Impeachment Hearing. March, p. 25.

Hull, Adrian Prentice. Comparative Political Science: An Inventory and Assessment since the 1980 s. March, p. 117.

Jamieson, Kathleen Hall, Erika Falk, and Susan Scherr. The Enthymeme Gap in the 1996 Presidential Campaign. March, p. 13.

Jefferson, Kurt W. The Bosnian War Crimes Trial Simulation: Teaching Students about the Fuzziness of World Politics and International Law. September, p. 589.

Jeffries, Judson L. U.S. Senator Edward W. Brooke and Governor L. Douglas Wilder Tell Political Scientists How Blacks Can Win High-Profile Statewide Office. September, p. 583.

Kathlene, Lyn, and Judd Choate. Running for Elected Office: A Ten-Week Political Campaign Simulation for Upper-Division Courses. March, p. 69.

Kiasatpour, Soleiman M. The Internet and Film: Teaching Middle East Politics Interactively. March, p. 83.

Kincaid, John. Federal Democracy and Liberty. June, p. 211.

Knack, Stephen. Drivers Wanted: Motor Voter and the Election of 1996. June, p. 237.

Knotts, H. Gibbs, and Eleanor C. Main. Teaching Ph.D. Students to Teach Political Science: The Emory TATTO Program. September, p. 607.
Kumar, Martha Joynt. The Rise and Growth of American Politics: A Sketch of Constitutional Development. June, p. 227.

Lax, Jeffrey R. Fair Division: A Format for the Debate on the Format of Debates. March, p. 45.

Leonard, Stephen T. "Pure Futility and Waste": Academic Political Science and Civic Education. December, p. 749.

Leonard, Stephen T. Making the Past into Prologue: A Response to Professor Bennett. December, p. 758.

Lieske, Joel. Tocqueville and Democracy in America: An Introduction. June, p. 195.

Lieske, Joel. Race and Democracy. June, p. 217.

Lorenzo, David J. Countering Popular Misconceptions of Federal Bureaucracies in American Government Classes. December, p. 743.

Mann, Sheilah. What the Survey of American College Freshmen Tells Us about Their Interest in Politics and Political Science. June, p. 263.

Mantellasche, Dagobert D. Otto Q. Besser-Wisser: An Appreciation of the Pioneer of Post-Distanciationalist Politometrics. December, p. 730.

McDowell, Gary L. From the Halls of Congress: Political Scientists Testify during Impeachment Hearing. March, p. 24.

Melcher, James P. "Bringing It All Back Home": The Issues Involved in Teaching a U.S. Regional Politics Course. March, p. 77.

Miller, Arthur H. Sex, Politics, and Public Opinion: What Political Scientists Really Learned from the ClintonLewinsky Scandal. December, p. 721.

Muir, Edward. They Blinded Me With Political Science: On the Use of Nonpeer-Reviewed Research in Education Policy. December, p. 762.

Pious, Richard M. Henry Jones Ford: The Political Science of Forecasting. June, p. 235.

Rosenthal, Cindy Simon. One Experience is Worth a Thousand Words: Engaging Undergraduates in Field Research on Gender. March, p. 63.

Rozell, Mark J., and Clyde Wilcox. The Clinton Scandal in Retrospect. September, p. 539.

Rozell, Mark J. Something to Hide: Clinton's Misuse of Executive Privilege. September, p. 550.

Rudder, Catherine E. Executive Director's Report. September, p. 629.

Sarkees, Meredith Reid, and Nancy E. McGlen. Misdirected Backlash; The Evolving Nature of Academia and the 
Status of Women in Political Science. March, p. 100.

Shestopal, Helen. Observations on the Transformation of the Political Science Community in Post-Soviet Russia. December, p. 713.

Sigel, Roberta. Gender and Voting Behavior in the 1996 Presidential Election: An Introduction. March, p. 5.

Singer, Peter. The Thucydides Tapes. September, p. 596.

Siplon, Patricia. Scholar, Witness, or Activist? The Lessons and Dilemmas of an AIDS Research Agenda. September, p. 577.

Siplon, Patricia. A Brief History of the Political Science of AIDS Activism. September, p. 578.

Skowronek, Stephen. Henry Jones Ford on the Development of American Institutions. June, p. 233.

Somit, Albert, and Steven A. Peterson. Rational Choice and Biopolitics: A (Darwinian) Tale of Two Theories. March, p. 39.

Sonner, Molly W., and Clyde Wilcox. Forgiving and Forgetting: Public Support for Bill Clinton during the Lewinsky Scandal. September, p. 554.

Spitzer, Robert J. Clinton's Impeachment Will Have Few Consequences for the Presidency. September, p. 541.

Splaine, John. Tocqueville's Journey on C-SPAN. June, p. 197.

Sunstein, Cass R. From the Halls of Congress: Political Scientists Testify during Impeachment Hearing. March, p. 25.

Waltz, Kenneth N. Globalization and Governance. December, p. 693.

Wayne, Stephen J. Clinton's Legacy: The Clinton Persona. September, p. 558.

West, Darell. Lessons of a Political Science Webcaster. December, p. 732.

Zeiser, Pamela, A. Teaching Process and Product: Crafting and Responding to Student Writing Assignments. September, p. 593.

\section{Author Index by Subject}

\section{American Politics}

Ackerman, Bruce. From the Halls of Congress: Political Scientists Testify during Impeachment Hearing. March, p. 24.

Andres, Gary. Observations on a PostGingrich House. September, p. 571.

Beer, Samuel H. From the Halls of Congress: Political Scientists Testify during Impeachment Hearing. March, p. 25.

Edwards, George C. III. Henry Jones Ford and the American Presidency. June, p. 229.

Elazar, Daniel J. Tocqueville and the Cultural Basis of American Democracy. June, p. 207.
Fisher, Louis. Starr's Record as Independent Counsel. September, p. 546.

Frantzich, Stephen. Teaching through Tocqueville. June, p. 203.

Frederickson, H. George. The Repositioning of American Public Administration. December, p. 701.

Holden Jr., Matthew. From the Halls of Congress: Political Scientists Testify during Impeachment Hearing. March, p. 25.

Kincaid, John. Federal Democracy and Liberty. June, p. 211.

Lieske, Joel. Tocqueville and Democracy in America: An Introduction. June, p. 195.

Lieske, Joel. Race and Democracy. June, p. 217.

McDowell, Gary L. From the Halls of Congress: Political Scientists Testify during Impeachment Hearing. March, p. 24.

Rozell, Mark J., and Clyde Wilcox. The Clinton Scandal in Retrospect. September, p. 539.

Rozell, Mark J. Something to Hide: Clinton's Misuse of Executive Privilege. September, p. 550.

Sonner, Molly W., and Clyde Wilcox. Forgiving and Forgetting: Public Support for Bill Clinton during the Lewinsky Scandal. September, p. 554.

Splaine, John. Tocqueville's Journey on C-SPAN. June, p. 197.

Sunstein, Cass R. From the Halls of Congress: Political Scientists Testify during Impeachment Hearing. March, p. 25.

Spitzer, Robert J. Clinton's Impeachment Will Have Few Consequences for the Presidency. September, p. 541.

Wayne, Stephen J. Clinton's Legacy: The Clinton Persona. September, p. 558.

\section{Civic Education}

Bennett, Stephen Earl. The Past Need Not Be Prologue: Why Pessimism About Civic Education Is Premature. December, p. 755 .

Bennett, Stephen Earl. Rebuttal to Response by Stephen Leonard. December, p. 760.

Ehrlich, Thomas. Civic Education: Lessons Learned. June, p. 251.

Leonard, Stephen T. "Pure Futility and Waste": Academic Political Science and Civic Education. December, p. 749.

Leonard, Stephen T. Making the Past into Prologue: A Response to Professor Bennett. December, p. 758.

\section{Computer Applications}

West, Darell. Lessons of a Political Science Webcaster. December, p. 732.
Elections, Electoral Processes, and Political Parties

Abramowitz, Alan I. Explaining Success and Failure in the 1998 Midterm Elections: Comparing the Influence of Swing Voters and Core Party Supporters. March, p. 60.

Dulio, David A., Donald L. Goff, and James A. Thurber. Untangled Web: Internet Use during the 1998 Election. March, p. 53.

Jeffries, Judson L. U.S. Senator Edward W. Brooke and Governor L. Douglas Wilder Tell Political Scientists How to Win High-Profile Statewide Office. September, p. 583.

Knack, Stephen. Drivers Wanted: Motor Voter and the Election of 1996. June, p. 237.

Lax, Jeffrey R. Fair Division: A Format for the Debate on the Format of Debates. March, p. 45.

\section{Political Communication}

Almond, Gabriel, with Wolfgang Krauss. The Size and Composition of the Anti-Nazi Opposition in Germany. September, p. 563.

\section{Political Economy}

Waltz, Kenneth N. Globalization and Governance. December, p. 693.

\section{Political Science Education}

Brock, Kathy L., and Beverly J. Cameron. Enlivening Political Science Courses with Kolb's Learning Preference Model. June, p. 251.

Hallerberg, Mark, and Bettina Cothran. German Politics auf Deutsch: Teaching Comparative Politics in a Language Across the Curriculum Format. December, p. 739.

Jefferson, Kurt W. The Bosnian War Crimes Trial Simulation: Teaching Students about the Fuzziness of World Politics and International Law. September, p. 589.

Kathlene, Lyn, and Judd Choate. Running for Elected Office: A Ten-Weck Political Campaign Simulation for Upper-Division Courses. March, p. 69.

Kiasatpour, Soleiman M. The Internet and Film: Teaching Middle East Politics Interactively. March, p. 83.

Lorenzo, David J. Countering Popular Misconceptions of Federal Bureaucracies in American Government Classes. December, p. 743.

Melcher, James P. "Bringing It All Back Home": The Issues Involved in Teaching a U.S. Regional Politics Course. March, p. 77.

Rosenthal, Cindy Simon. One Experience is Worth a Thousand Words: Engaging Undergraduates in Field Research on Gender. March, p. 63. 
Singer, Peter. The Thucydides Tapes. September, p. 596.

Zeiser, Pamela, A. Teaching Process and Product: Crafting and Responding to Student Writing Assignments. September, p. 593.

\section{The Profession and Discipline of}

\section{Political Science}

Anonymous and Anonymous. Tenure in a Chilly Climate. March, p. 91.

Bowman, Darcia. The APSA Congressional Fellowship Program: A Job With Options. September, p. 647.

Cook, Timothy E. Treasurer's Report. December, p. 812.

Durfee, Mary. The Small, Remote, or Odd College: Making the Most Out of Your New Teaching Position. March, p. 109.

Finifter, Ada W. APSR Editor's Report. December, p. 803.

Garand, James C., and Kristy Graddy. Ranking Political Science Departments: Do Publications Matter? March, p. 113.

Goodson, Larry P., Bradford Dillman, and Anil Hira. Ranking the Presses: Political Scientists' Evaluations of Publisher Quality. June, p. 257.

Gourevitch, Peter. Robert O. Keohane: A Biography. September, p. 623.

Hargrove, Erwin C. Political Science Then and Now: Thoughts on Henry Jones Ford. June, p. 231.

Hull, Adrian Prentice. Comparative Political Science: An Inventory and As- sessment since the 1980s. March, p. 117.

Knotts, H. Gibbs, and Eleanor C. Main. Teaching Ph.D. Students to Teach Political Science: The Emory TATTO Program. September, p. 607.

Kumar, Martha Joynt. The Rise and Growth of American Politics: A Sketch of Constitutional Development. June, p. 227.

Mann, Sheilah. What the Survey of American College Freshmen Tells Us about Their Interest in Politics and Political Science. June, p. 263.

Mantellasche, Dagobert D. Otto Q. Besser-Wisser: An Appreciation of the Pioneer of Post-Distanciationalist Politometrics. December, p. 730.

Miller, Arthur H. Sex, Politics, and Public Opinion: What Political Scientists Really Learned from the ClintonLewinsky Scandal. December, p. 721.

Muir, Edward. They Blinded Me With Political Science: On the Use of Nonpeer-Reviewed Research in Education Policy. December, p. 762.

Pious, Richard M. Henry Jones Ford: The Political Science of Forecasting. June, p. 235.

Rudder, Catherine E. Executive Director's Report. September, p. 629.

Sarkees, Meredith Reid, and Nancy E. McGlen. Misdirected Backlash: The Evolving Nature of Academia and the Status of Women in Political Science. March, p. 100.
Shestopal, Helen. Observations on the Transformation of the Political Science Community in Post-Soviet Russia. December, p. 713.

Somit, Albert, and Steven A. Peterson. Rational Choice and Biopolitics: A (Darwinian) Tale of Two Theories. March, p. 39.

Siplon, Patricia. Scholar, Witness, or Activist? The Lessons and Dilemmas of an AIDS Research Agenda. September, p. 577.

Siplon, Patricia. A Brief History of the Political Science of AIDS Activism. September, p. 578.

Skowronek, Stephen. Henry Jones Ford on the Development of American Institutions. June, p. 233.

\section{Women and Politics}

Andersen, Kristi. The Gender Gap and Experiences with the Welfare State. March, p. 17.

Carroll, Susan J. The Disempowerment of the Gender Gap: Soccer Moms and the 1996 Elections. March, p. 7.

Frankovic, Kathleen A. Why the Gender Gap Became News in 1996. March, p. 20.

Jamieson, Kathleen Hall, Erika Falk, and Susan Scherr. The Enthymeme Gap in the 1996 Presidential Campaign. March, p. 13.

Sigel, Roberta. Gender and Voting Behavior in the 1996 Presidential Election: An Introduction. March, p. 5. 